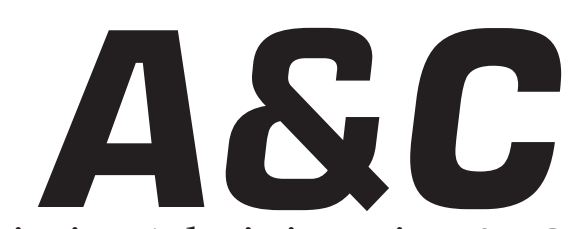

Revista de Direito Administrativo \& Constitucional

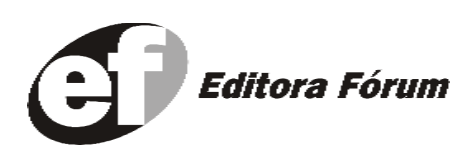

A\&C R. de Dir. Administrativo e Constitucional, Belo Horizonte, ano 4, n.16, p. 1-255, abr.jun. 2004 


\section{A\&C REVISTA DE DIREITO ADMINISTRATIVO E CONSTITUCIONAL}

\section{IPDA}

Instituto Paranaense

de Direito Administrativo

Direção Geral

Romeu Felipe Bacellar Filho

Direção Editorial

Paulo Roberto Ferreira Motta

Direção Executiva

Emerson Gabardo

Conselho de Redação

Edgar Chiuratto Guimarães

Adriana da Costa Ricardo Schier

Célio Heitor Guimarães

Conselho Editorial

\section{Adilson Abreu Dallari Lúcia Valle Figueiredo}

Alice Gonzáles Borges Manoel de Oliveira Franco Sobrinho

Carlos Ari Sundfeld (in memoriam)

Carlos Ayres Britto Marçal Justen Filho

Carlos Delpiazzo Marcelo Figueiredo

Cármen Lúcia Antunes Rocha Márcio Cammarosano

Celso Antônio Bandeira de Mello Maria Cristina Cesar de Oliveira

Clèmerson Merlin Clève Nelson Figueiredo

Clóvis Beznos Odilon Borges Junior

Enrique Silva Cimma Pascual Caiella

Eros Roberto Grau Paulo Eduardo Garrido Modesto

Fabrício Motta Paulo Henrique Blasi

Guilhermo Andrés Muñoz Paulo Neves de Carvalho

Jorge Luís Salomoni Paulo Ricardo Schier

José Carlos Abraão Pedro Paulo de Almeida Dutra

José Eduardo Martins Cardoso Regina Maria Macedo Nery Ferrari

José Luís Said Rogério Gesta Leal

José Mario Serrate Paz Rolando Pantoja Bauzá

Juan Pablo Cajarville Peruffo Sérgio Ferraz

Juarez Freitas Valmir Pontes Filho

Julio Rodolfo Comadira Yara Stropa

Luís Enrique Chase Plate Weida Zancaner

Os conceitos emitidos em trabalhos assinados são de responsabilidade de seus autores, que gozam de inteira liberdade de opinião. e-mail para remessa de artigos, pareceres e contribuições: e.gab.@uol.com.br

ou conselho@editoraforum.com.br Endereço para envio de contribuições: Editora Fórum

Revista A\&C, Av. Afonso Pena, 2770, 15\%16ª andar, Funcionários, CEP 30130-007 - Belo Horizonte - MG

A\&C Revista de Direito Administrativo e Constitucional. Ano 3, n. 11, jan./mar. 2003. Belo Horizonte: Fórum, 2003.

Trimestral

ano 1, n.1, 1999 até ano 2, n.10, 2002 publicada pela Editora Juruá em Curitiba

ISSN: $1516-3210$

1. Direito Administrativo. 2. Direito Constitucional. I. Fórum.

CDD: 342 CDU: 33.342
Editor responsável: Luis Cláudio Rodrigues Ferreira Projeto gráfico: Luis Alberto Pimenta

Diagramação: Anderson Pimenta

Revisora: Olga M. A. Sousa

Pesquisa jurídica: Fátima Ribeiro - OAB/MG 74868 Bibliotecária: Nilcéia Lage de Medeiros -

CRB 1545/MG - 6 a região

(C) Editora Fórum Ltda 2004.

Proibida a reprodução total ou parcial desta obra, por qualquer meio eletrônico, inclusive por processos xerográficos, sem autorização expressa do editor.

Distribuída em todo o território nacional

Assinaturas e comercialização:

Editora Fórum, Av. Afonso Pena, 2770, 15-16 andar, Funcionários, CEP 30130-007 - Belo Horizonte - MG Tel.: (31) 2121-4900 - 0800 704-3737

e-mail: editoraforum@editoraforum.com.br site: www.editoraforum.com.br 


\title{
Âmbito de Validade da Lei de Processo Administrativo (Lei no 9.784/99) - para além da Administração Federal
}

\author{
Bernardo Strobel Guimarães* \\ Mestrando em Direito Administrativo na Universidade de São Paulo - USP. Especialista em Direito \\ Administrativo pelo IDRFB. e em Direito Tributário pela PUC/PR
}

\begin{abstract}
Sumário: 1 Introdução - 2 Comentários ao caput: Âmbito de incidência da Lei de Processo Administrativo - para além da Administração Federal - 2.2 Distinção entre processo e procedimento como pressuposto necessário para fixação da incidência da LPAF e suas contingências - 2.3 Fixação do alcance da Lei e interpretação possível da reserva Federativa do seu art. $1^{\circ}$, caput - 3 Comentários ao $\S 1^{\circ}$ : Do exercício da função administrativa como critério de fixação da incidência da Lei no ${ }^{\circ}$ 9.784/99 - 4 Comentários ao §2: Impossibilidade de se determinar a incidência da LPAF exclusivamente pelo critério orgânico ou subjetivo - $\mathbf{5}$ Conclusões pontuais
\end{abstract}

\section{Introdução}

Nada obstante a Lei de Processo Administrativo não figurar propriamente entre as novidades do direito administrativo brasileiro, muito ainda há de se trabalhar com ela para que se fixe seu real alcance, firmando-se, de vez por todas, as reais possibilidades de seu manejo. ${ }^{1}$ Muito do instrumental contido na Lei $\mathrm{n}^{\circ}$ 9.784/99 (LPAF) ainda carece de ser estudado com os rigores que o tema exige e, portanto, aplicado de maneira corriqueira.

Aliás, o momento para repensar a Lei de Processo Administrativo não poderia ser mais propício, haja vista as próprias alterações que se fazem sentir no bojo do direito administrativo. Um dos pontos onde manifestamente a mudança manifesta-se é na necessidade, cada vez maior, de justificar-se o exercício da função administrativa. Este influxo, mais do que impor a necessidade de se repensar o alcance da "motivação" dos atos estatais, predica a necessidade de haver canais arejados e efetivos de diálogo entre o cidadão e a Administração Pública. Cada vez mais, se caminha

\footnotetext{
< bernardo.guimarães@bol.com.br>

${ }^{1}$ Acerca da atualidade e possibilidades em aberto do tema, eloqüentes as palavras de SUNDFELD, Carlos Ari: "O direito administrativo brasileiro sofreu, em 1999, um impacto cujos efeitos devem se fazer sentir nos próximos anos, podendo-se antever sua significativa transformação. A razão é o surgimento de duas leis gerais sobre processo (ou procedimento) administrativo" (Processo e Procedimento Administrativo no Brasil. In: As Leis do Processo Administrativo - Lei Federal 9.784/99 e Lei Paulista 10.177/98. São Paulo: Malheiros, 2.000, p. 17).
} 
para um direito administrativo de "Estado" e, pois, constitucional, deixando para trás um paradigma de direito administrativo de "Governo". Está-se a preferir o interesse público primário em detrimento do secundário, o que manifestamente não pode prescindir do diálogo entre os diferentes atores da relação estatal, que tem como seu vértice necessário o cidadão. Diálogo este do qual o cidadão foi, por muito tempo, alijado.

Diante deste quadro de alteração do direito administrativo inaugurado pela Constituição de 1988 o processo administrativo ganha status constitucional, justamente, por ser via idônea para que se instaure o diálogo entre a Administração Pública e os cidadãos. Mais do que o atendimento do seu caminho lógico, deve a ação administrativa demonstrar que vem a pôr em marcha reclames legítimos que vão ao encontro do interesse público. Nesta quadra, o processo administrativo ganha relevo como forma de legitimação do agir estatal, e, por definição da Constituição, justificação do próprio exercício do "poder". ${ }^{2}$

Conclui-se, pois, que o processo administrativo, máxime em função de sua indole constitucional, é dos instrumentos mais poderosos para que se tenha um exercício democrático e legítimo do agir estatal. Infelizmente, esta ferramenta é subutilizada, deixando baldo de sentido um importante quadrante da Constituição.

Não por outra razão afirmou recentemente o Superior Tribunal de Justiça em acórdão que cuida do tema: " "A Lei $9.784 / 99$ é, certamente, um dos mais importantes instrumentos de controle do relacionamento entre Administração $e$ Cidadania. Seu dispositivos trouxeram para nosso Direito Administrativo, o devido processo legal. Não é exagero dizer que a Lei 9.784/99 instaurou no Brasil, o verdadeiro Estado de Direito."

Neste espírito, um dos pontos que ainda está a merecer análise adequada da doutrina e da jurisprudência é a fixação adequada do âmbito de validade da Lei Federal de Processo Administrativo (LPAF). Não bastasse por si só ser movediço o trato com a referida Lei, razões de índole constitucional concorrem para o fenômeno de sua subutilização; aliandose à timidez com que se tem manejado a Lei $\mathrm{n}^{\mathrm{o}} 9.784 / 99$, soma-se a própria incerteza que ainda gera o fenômeno da processualidade no âmbito da Administração erigido pela Constituição.

\footnotetext{
${ }^{2}$ Anota sobre o tema MOREIRA NETO, Diogo de Figueiredo: "Com efeito, a idéia do processo como instrumen to de legitimação na filosofia moderna, especialmente na ética política, fruto da racionalidade argumentativa, tem merecido a atenção dos mais conspícuos pensadores do Direito contemporâneo." (Direito Regulatório. Rio de Janeiro: Renovar, 2003, p. 156).

3 STJ, 1a SEÇÃO, MS 8946/DF, Rel. Min. Humberto Gomes de Barros, j. 22.10.2003, DJ 17 nov. 2003, p. 197.
}

A \& C R. de Dir. Administrativo e Constitucional, Belo Horizonte, ano 4, n. 16, p. 193-218, abr./jun. 2004 
Feito este aporte introdutório, à guisa de estado da arte, cabe justificar minimamente o presente ensaio.

Como já se teve o ensejo de se deixar entrever, o eixo lógico-jurídico que permite elucidar o grosso das dúvidas em relação à LPAF reside em seu cotejo com as disposições constitucionais que dão conteúdo e suporte à processualidade administrativa. Destarte, qualquer dúvida em relação aos limites e possibilidades de aplicação da LPAF deve remeter o intérprete, de imediato, ao Texto Magno.

Com este cuidado (ao menos uma pretensão sincera neste sentido), abordase questão que se julga fundamental para emprego da Lei, qual seja fixar com acerto o seu âmbito de aplicação.

Para tanto, optou-se por tecer as considerações pertinentes ao tema diretamente referidas ao seu art. $1^{\circ}$, fazendo-se assim as ponderações que se julgam necessárias a suportar as inferições havidas, com imediata referência ao enunciado da lei. Este método, se bem que pouco utilizado de forma pontual, tem a virtude de dar maior concretude ao labor teórico que se pretende desenvolver, pois possibilita imediata referibilidade entre as razões da Lei e da Constituição, desvelando os aspectos práticos do labor jurídico.

Antes ainda de empreender a análise que se pretende do art. $1^{\circ}$ da Lei $\mathrm{n}^{\mathrm{o}} 9.784 / 00$, necessita-se, ainda que minimamente, fixar o ponto de vista usual acerca da questão que, adianta-se, busca ser refutado nesse ensaio.

A opinião mais difundida acerca do âmbito de aplicação da Lei de Processo Administrativo, fazendo análise meramente gramatical, identifica que esse plexo normativo incide sobre as relações desenvolvidas no seio da Administração Federal direta e indireta. Nada além, nada aquém. ${ }^{4}$

Por fim, em sendo essa a opinião usual acerca do tema, e por manifestamente o presente texto se afastar dessa orientação, cabe desde logo, à moda de José Souto Maior Borges, fazer uma apologia do erro, ${ }^{5}$ ressalvando de antemão a possibilidade do equívoco. Isso pois, caso não se logre demonstrar nenhuma das propostas ora esposadas, por certo restará o consolo de ter levado a efeito tentativa sincera de contribuir para a análise do fenômeno "processo administrativo".

Seguindo esta linha, cabe pôr em mira o objeto primeiro do estudo pretendido:

Art. $1^{\circ}$ - Esta Lei estabelece normas básicas sobre o processo administrativo

\footnotetext{
${ }^{4}$ Nesse sentido consultar os comentários ao art. $1^{\circ}$ da Lei Geral de Processo Administrativo na seguinte obra de CARVALHO FILHO, José dos Santos. Processo Administrativo Federal - comentários à Lei 9.784 de 29.01.1999. Rio de Janeiro: Lumen Juris, 2001, p. 38 et seq.

5 SOUTO MAIOR BORGES, José. Ciência Feliz. 2. ed. São Paulo: Max Limonad, 2000.
}

A \& C R. de Dir. Administrativo e Constitucional, Belo Horizonte, ano 4, n. 16, p. 193-218, abr./jun. 2004 
no âmbito da Administração Federal direta e indireta, visando, em especial, à proteção dos direitos dos administrados e ao melhor cumprimento dos fins da Administração.

$\S 1^{\circ}$ Os preceitos desta Lei também se aplicam aos órgãos dos Poderes Legislativo e Judiciário da União, quando no desempenho de função administrativa. $\S 2^{\circ}$ Para os fins desta Lei, consideram-se:

I - órgão - a unidade de atuação integrante da estrutura da Administração direta e da estrutura da administração indireta;

II - entidade - a unidade de atuação dotada de personalidade jurídica;

III - autoridade - o servidor ou agente público dotado de poder de decisão.

Fixado o objeto do estudo, cumpre analisá-lo à luz da Carta Magna, fazendo releitura dos seus termos e buscando possibilitar um novo ponto de vista acerca da matéria. É justamente uma interpretação constitucionalmente conforme do instituto, a única pretensão que se permite nesse artigo.

\section{Comentários ao caput: âmbito de incidência da Lei de Processo Administrativo - para além da Administração Federal}

Problema sempre tormentoso de hermenêutica é firmar adequadamente o leque de situações que estão sob a égide da norma interpretada; é um dos problemas clássicos que se põem ao jurista. Imprescindível, assim, fixar a abrangência da Lei $n^{\circ}$ 9.784/99, haja vista a leitura usual levar a uma resposta que, crê-se, não se sustenta diante de nosso sistema jurídico, em especial da Constituição Federal de 1988.

O primeiro artigo da Lei de Processo Administrativo federal busca (como tantas outras) determinar o âmbito de aplicação desta lei. Neste passo, a primeira impressão que se extrai do texto é a pretensão de a lei incidir no âmbito da Administração Federal, tanto direta quanto indireta (interpretação gramatical). Esta assertiva é, seguramente, verdadeira, no entanto não responde por completo à questão do âmbito de incidência da Lei $\mathrm{n}^{\circ}$ 9.784/99 e não pode ser tomada de maneira a excluir outras hipóteses.

Superada a óbvia constatação de a lei se aplicar ao âmbito federal, cumpre ir além: ou seja, perquirir se a lei teria aptidão para disciplinar situações que, porventura, se desenvolvam além da esfera Federal, no âmbito da Administração Pública Estadual ou Municipal.

Crê-se que a resposta é de todo afirmativa, por contingências de ordem constitucional que passam a ser explicitadas. Somente assim pode-se dar trato sistemático ao tema, logrando referir o art. $1^{\circ} \mathrm{em}$ nosso sistema constitucional que deu plena guarida ao processo administrativo. ${ }^{6}$

A \& C R. de Dir. Administrativo e Constitucional, Belo Horizonte, ano 4, n. 16, p. 193-218, abr./jun. 2004 
Como primeiro argumento a ser alegado em favor da não exclusividade desta lei aplicar-se somente à Administração Federal, trazse a prescrição contida no seu próprio art. $1^{\circ}$, caput, in fine - “(...) visando, em especial, à proteção dos direitos dos administrados e ao melhor cumprimento dos fins da Administração". Necessário, assim, discorrer minimamente acerca dos fins da Administração e do direito dos administrados.

Da mais elementar leitura do art. 37 da CF/88 infere-se que os fins primeiros a que se submete a atividade administrativa revestem-se de hierarquia constitucional e vinculam toda a Administração, seja na esfera de competência da União, seja na dos Estados, Distrito Federal e Municípios. O mesmo fenômeno se dá em relação aos direitos inerentes à qualidade de cidadão administrado que, por serem outorgados pelo Texto Magno, na qualidade de normas centrais ${ }^{7}$ estão indenes a qualquer desnaturação mesmo se perpetrada sob a invocação do princípio federativo.

Com efeito, o princípio federativo tem o propósito justamente de garantir o máximo atendimento dos direitos fundamentais. ${ }^{8}$ A partição constitucional de competências entre os entes federados funda-se na suposição de que diferentes ordens políticas, cada qual ocupando um campo de atuação definido (i.e. competência), possibilita um atendimento mais imediato dos direitos fundamentais.

A repartição constitucional de competências contém em seu bojo o ideal de que cada pessoa política tem mais aptidão para concretizar certos valores cuja competência, por esta razão, é a si outorgada pela Constituição. Note-se que há certos valores que, inclusive, devem ser tratados de maneira conjunta para serem concretizados de maneira adequada. $\mathrm{O}$ atendimento dos valores constitucionalmente tutelados é o critério retor da partição de competências federativas engendrada pelo constituinte originário. ${ }^{9}$

Tal conclusão se alcança, especialmente, da análise das competências concorrentes $(\mathrm{CF} / 88$, art. 24) que se justificam precisamente sob o influxo

\footnotetext{
$\overline{6}$ "Todos são iguais perante a lei, sem distinção de qualquer natureza, garantindo-se aos brasileiros e aos estrangeiros residentes no País a inviolabilidade do direito à vida, à liberdade, à igualdade, à segurança e à propriedade, nos termos seguintes: (...) aos litigantes, em processo judicial ou administrativo, e aos acusados em geral são assegurados o contraditório e a ampla defesa, com os meios e recursos a ela inerentes" (CF/88, art. 5०, LV)

${ }^{7}$ Classificação de MACHADO HORTA, Raul. Estudos de Direito Constitucional. Belo Horizonte: Del Rey, 1995, p. 390-393.

${ }^{8}$ Sobre o tema Estado Federativo consulte-se, por referência obrigatória: MACHADO HORTA, Raul, op. cit., p. 345-522

${ }^{9}$ Aliás, quer nos parecer que toda partição de competência se dá para melhor atendimento das finalidades que justificam a sua própria existência. Com efeito, o exercício das competências só se faz legítimo face à satisfação das finalidades públicas que as justificam, sendo que todo exercício de poder deve orientar-se para este fim, inclusive as especializações.
} 
dos argumentos expostos, na medida em que certos valores, para serem curados de maneira adequada, exigem a composição entre diferentes ordens federativas.

A atribuição de competências distintas entre diferentes entes federais não é um fim que se baste em si, e visa, pois, a garantir o máximo atendimento de valores constitucionalmente tutelados, especialmente direitos e garantias individuais. É a legitimação democrática do poder que coloca todo exercício do poder sob o influxo do exercício de uma função. Ou seja, o princípio federativo busca dar guarida também a outros valores constitucionais e existe como maneira de instrumentalizá-los. A repartição federativa de competências é a maneira que o constituinte julgou escorreita para a realização dos diversos fins a serem perseguidos por nosso Estado Constitucional.

As regras contidas na Lei de Processo Administrativo claramente buscam garantir o atendimento dos fins da Administração e os direitos dos administrados; ambos os conceitos revestem-se de dignidade constitucional e, não só podem, como devem, ser concebidos de maneira parelha em toda nossa Federação. Com efeito, esse condicionamento se impõe até em face do exercício das competências federativas que, quando exercidas, devem guardar respeito a essas balizas. Não se concebe que qualquer ente da Federação venha a exercer suas competências descurando dos valores: direitos dos administrados e finalidades da Administração.

Não haveria sentido em se conceber que os fins da Administração Pública no Estado do Sergipe ou no Município de Curitiba fossem outros senão os mesmos fins da Administração Federal, tudo em conformidade e na acepção empregada pelo art. 37 da CF/88.

Também seria inviável considerar que os direitos conferidos aos cidadãos inerentes a esta qualidade, quando no trato com a Administração Federal, fossem diversos dos que lhes são conferidos quando jungidos à esfera Estadual ou Municipal.

Tanto os princípios que sujeitam a ação administrativa, quanto os direitos dos cidadãos, são conformes ao longo de toda nossa Federação na medida em que esse termo for buscado na Constituição e na medida em que as diversas pessoas políticas só legislam em atenção, e dando guarida, a tais predicados.

Ou seja, há um mínimo conferido pela Constituição que não está sujeito a temperamentos, caracterizando o "núcleo duro" de nossa função

A \& C R. de Dir. Administrativo e Constitucional, Belo Horizonte, ano 4, n. 16, p. 193-218, abr./jun. 2004 
administrativa, que é definido pela própria Carta Magna e implica em respeito aos direitos dos cidadãos e às finalidades da Administração.

Com a assertiva não se pretende negar dignidade às contingências de nosso esquema federativo e à possibilidade de haver regramentos distintos concebidos por diferentes pessoas políticas. Apenas se explicitam os eixos de sua racionalidade, conferidos pela própria Constituição Federal. Cumpre explicitar melhor a idéia.

Com efeito, os diferentes âmbitos onde se concebe o exercício de função administrativa (União, Estados, Distrito Federal e Municípios) e se reconhece inclusive capacidade para legislar acerca de direito administrativo, devem guardar no exercício dessas funções estreita consonância com a Carta Magna. Pode-se dizer mais.

O exercício destas competências só se faz legítimo em se atendendo rigorosamente as contingências de ordem Constitucional, que fixam os valores ótimos do sistema, a serem perseguidos e concretizados pelas diferentes ordens legais. Neste passo, só tem sentido o exercício das competências legislativas (e sua própria repartição federativa) para integrar e efetivar os valores postos pela ordem constitucional que são os vetores que condicionam todo o agir estatal (nas funções de administrar, julgar e legislar).

Pesquisa mais minuciosa empreendida no nosso sistema Constitucional é necessária para que se fixe o regime que a Constituição outorgou ao "processo administrativo" à guisa de definir seu âmbito de incidência. Para tanto, mister enunciar de plano o conteúdo que os princípios da ampla defesa e do contraditório (direitos fundamentais) assumem em nosso Estado (concebido como República Federativa):

Art. $5^{\circ}$ - Todos são iguais perante a lei, sem distinção de qualquer natureza, garantindo-se aos brasileiros e aos estrangeiros residentes no País a inviolabilidade do direito à vida, à liberdade, à igualdade, à segurança e à propriedade, nos termos seguintes:

(...)

LV - aos litigantes, em processo judicial ou administrativo, e aos acusados em geral são assegurados o contraditório e ampla defesa, com os meios e recursos a ela inerentes; (grifou-se).

Numa primeira aproximação com o conteúdo da norma constitucional que garante o contraditório e a ampla defesa aos litigantes e acusados, é de se ressaltar, fazendo-se o necessário cotejo com o caput do artigo $5^{\circ}$, que não há discriminação no seio da Federação possível de ser levada a 
cabo de maneira constitucionalmente eficaz no que tange ao exercício destes direitos.

Ou seja, não hão de se operar, no que toca à integridade do contraditório e da ampla defesa (i.e. em relação ao processo), distinções de natureza alguma entre brasileiros, por toda a Federação, e estrangeiros. Todos fazem jus a ser tratados de maneira íntegra, sendo-lhes garantido o devido processo legal onde quer que se encontrem. Com efeito, contraditório e ampla defesa devem sempre ser franqueados quando se estiver a tratar de processo. Veja-se que tais conceitos condicionam todo o exercício do poder público; não só a Administração, mas também o exercício das funções legislativa e judicial.

Como primeira premissa, fixe-se que não há possibilidade de se conceber duas maneiras distintas de se operar o devido processo legal em nossa Federação. Sequer a alusão ao princípio federativo (como pretendido na Lei) teria o condão de alterar esta constatação, pois revestida da mais alta índole constitucional. A garantia é íntegra e não pode ser alijada em seu conteúdo, vinculando todas as pessoas políticas que integram nossa Federação ao seu pleno atendimento.

O devido processo legal, quer seja no processo administrativo, quer seja no judicial, não pode ser concebido de maneira diversa em duas entidades políticas distintas. Repisando a célebre lição de Celso Antônio Bandeira de Mello, invocando a Constituição, não há motivo jurídico apto a legitimar este discrímen. ${ }^{10}$

Resta, pois, a perplexidade da enunciação clara contida no caput do art. $1^{\circ}$ da Lei $\mathrm{n}^{\circ}$ 9.784/99 que afirma que a Lei "estabelece normas básicas sobre o processo administrativo no âmbito da Administração Federal". Cabe, pois, buscar fixar a amplitude a ser dada ao tema em estando minimamente explicitada a impossibilidade de se conceber ampla defesa e contraditório de maneira diversa ao longo de nossa Federação.

\subsection{Distinção entre processo e procedimento como pressuposto necessário para fixação da incidência da LPAF e suas contingências}

Para que bem se possa compor a questão e dar sentido à prescrição inaugural da Lei no 9.784/99 é necessário fixar, por imprescindível, a distinção entre processo e procedimento, distinção que, aliás, estribará o grosso das posições que serão adotadas no presente trabalho. Por vezes tomada

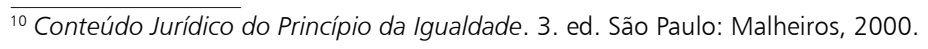

A \& C R. de Dir. Administrativo e Constitucional, Belo Horizonte, ano 4, n. 16, p. 193-218, abr.jun. 2004 
por inútil, crê-se que apenas a diferenciação entre os dois institutos permite fixar com propriedade o âmbito de incidência da Lei $n^{\circ} 9.784 / 99 .{ }^{11}$

Na raiz da distinção proposta está a própria prescrição do inc. LV do art. $5^{\circ}$ da $\mathrm{CF} / 88$ que identifica o fenômeno "processo" com a existência de "litigantes" e "acusados".

A prescrição une, pois, o devido processo legal (i.e. ampla defesa mais contraditório) à situação de conflituosidade entre os cidadãos e a Administração. Assim sendo, o processo é fenômeno que se junge de maneira indelével à noção de ampla defesa e contraditório assegurado a litigantes e acusados. Onde houver litigantes e acusados, surgirá o fenômeno do processo com suas garantias.

Caracteriza-se o processo como instituto jurídico qualificado pela necessidade de se assegurar a ampla defesa e o contraditório em face de situações de conflituosidade.

Processo administrativo pressupõe, destarte, a contraposição entre interesses; caso faleça esta nota de conflituosidade não se poderá denominar a relação havida de processo, conforme a acepção que lhe emprega a Constituição.

Tal constatação é de fácil verificação no âmbito da função judiciária, reconhecendo-se a qualidade de litigantes (ou acusados) às partes contendoras, sendo incontestável seu direito ao devido processo legal. Ninguém terá dúvida, v.g., em afirmar a absoluta nulidade de uma sentença que cercear o direito à prova de uma das partes ou que não a chamar ao processo de maneira eficaz. Não há problemas para que se admita a absoluta inaptidão de se reconhecer autoridade pública ao ato estatal que se pratique sem observância do contraditório e da ampla defesa, caso se esteja a exercer função jurisdicional.

Contudo, tal percepção é mais nebulosa em relação ao exercício da função administrativa, por razões eminentemente históricas, onde as situações de conflituosidade havidas entre Administração e cidadãos foram sempre, de hábito, chamadas de "procedimento". Impende fixar a acepção do fenômeno sob o sistema da Constituição para que a dúvida terminológica não passe a ser de conteúdo e acabe por gerar angustiamento de direitos/ garantias fundamentais.

O que não se pode admitir (como infelizmente se vê) é que o rótulo “procedimento" leve à insustentável conclusão de que, no seio da Ad-

\footnotetext{
${ }^{1}$ No sentido de ser indiferente a distinção ora levada a efeito, consulte-se: SUNDFELD, Carlos Ari. Processo e Procedimento Administrativo no Brasil. In: As Leis de Processo Administrativo - Lei Federal 9.784/99 e 10.177/98. São Paulo: Malheiros, 2000, especialmente a nota nº 5 nas p. 19 e 20.
} 
ministração, em se verificando "conflituosidade", esteja dispensado (ou abreviado) o devido processo legal e as garantias a ele inerentes, podendo haver o exercício de função administrativa que não atenda aos requisitos da ampla defesa e do contraditório.

A distinção não é meramente terminológica e o fenômeno processo no seio da Administração não se confunde com procedimento ${ }^{12}$ São maneiras radicalmente distintas do exercício das competências conferidas à Administração. A racionalidade entre as duas maneiras de atuar não pode ser confundida, sob pena de grassar a perplexidade e não se dar resposta adequada ao alcance da LPAF.

Neste sentido, aliás, vêm se pronunciando alguns autores, nada obstante estar longe de ser pacífica a distinção como aqui proposta. ${ }^{13}$ Romeu Felipe Bacellar, após fazer profunda análise nas letras jurídicas pátrias e estrangeiras acerca dos dois fenômenos, logra explicitar o que se entende por processo na seara administrativa com (de acordo com a linha ora adotada) absoluto rigor:

Quando à competência adiciona-se a colaboração de sujeitos e contraditório, o procedimento expressa-se como processo. O processo administrativo é forma de exteriorização da função administrativa qualificado pela participação de interessados em contraditório, imposto diante da circunstância de se tratar de procedimentos celebrados em preparação a um provimento (ato de poder imperativo por natureza e definição), capaz de interferir na esfera jurídica das pessoas. ${ }^{14} 15$

Do que se expôs, já se está a notar que o processo e o procedimento são realidades distintas, sendo que a noção de processo, onde quer que ele se manifeste, vincula-se (por injunção constitucional) à litigiosidade havida entre os sujeitos contendores, condição que, se verificada, lhes garante a ampla defesa e o contraditório.

Tanto o processo como o procedimento estão compreendidos no hiato lógico havido entre a existência prévia de um competência e o ato con-

\footnotetext{
12 Este pressuposto é tomado como "condição geral estipulativa", sem o qual sequer é possível tratar do fenômeno do processo no seio da Administração na obra que desde já indica-se como referência indispen sável, de BOCKMANN MOREIRA, Egon. Processo Administrativo Princípios Constitucionais e a Lei 9.784. São Paulo: Malheiros, 2000.

13 Para uma crítica profunda em relação à posição adotada e, como de estilo, incisiva consulte-se por todos JUSTEN FILHO, Marçal. "Considerações sobre o Processo Administrativo Fiscal". Revista Dialética de Direito Tributário, n. 33, p. 108.

14 BACELLAR, Romeu Felipe. Princípios Constitucionais do Processo Administrativo Disciplinar. São Paulo: Max Limonad, 1998, p. 48.

${ }^{15}$ Ainda, no mesmo sentido consulte-se a opinião da Lúcia Valle FIGUEIREDO (Curso de Direito Administrativo. 3. ed. São Paulo Malheiros, especialmente p. 379 et seq.).
} 
creto praticado no exercício desta competência. Contudo, isso não está a autorizar confusões terminológicas ou de conteúdo.

Pode-se dizer que ambos os fenômenos tratam da passagem de um plano abstrato gizado por norma para um plano concreto de atuação da Administração; no entanto, quando há litigiosidade, há exigência de se passar pelo crivo do contraditório e da ampla defesa, para a prática do ato. Em ambos os casos (processo e procedimento administrativo) haverá a prática de um ato administrativo ao fim; porém, no caso de este ato compor uma situação de litigiosidade ele deverá ser praticado sob a forja do devido processo legal, agregando essa condição para sua perfeição.

A dissimilitude entre os dois institutos situa-se, fundamentalmente, em relação a como se exercerá esta passagem, ou seja, quais os requisitos para que o ato final cumpra seus pressupostos e seja reconhecido como perfeito.

No procedimento, por falecer a nota de conflituosidade, não há necessidade de a Administração ater-se necessariamente às razões do cidadão, considerando-as expressamente (i.e, sob a pauta do contraditório) para proferir decisão. $\mathrm{O}$ ato final somente precisa atender os interesses da Administração definidos em lei, o que se dá pelo atendimento da forma escorreita para sua produção, bem como do atendimento inegociável das finalidades públicas definidas na lei e na Constituição.

No processo, haja vista a nota de conflituosidade havida, é imprescindível que o ato final a ser praticado (que põe fim, no seio da $A d$ ministração, ao conflito) possibilite a efetiva participação do cidadão. Precisamente, há de se reconhecer o ato final do processo como um ato que encerra um conflito, e por isto não prescinde de fazer valer as razões de ambas as partes, sopesando-as, para que seja produzido de forma juridicamente legítima. ${ }^{16}$ Aí, pois, reside a importância de se explicitar a identificação feita pelo Texto Magno entre o processo como fenômeno qualificado pela conflituosidade.

É a conflituosidade (seja por haver litigantes, seja por haver acusados) que torna imperativo dar possibilidade a ambas as partes manifestarem-se para a produção do ato final, pois é este ato final que comporá, no plano jurídico, a divergência. Romeu Felipe Bacellar, novamente, manifesta-se com clareza a respeito desta exigência:

\footnotetext{
${ }^{16}$ A nota característica do conflito jurídico se vincula à idéia de que na multiplicidade de mensagens transmi tidas pelo direito pode haver deficiência na sua transmissão, gerando expectativas frustradas perante às mensagens que o direito assume como válidas. É o magistério de FERRAZ JR., Tércio. Direito, Retórica e Comunicação. 2. ed. São Paulo: Saraiva, 1997.
} 
(...) o sentido reside na identificação de sujeitos processuais — litigantes e acusados — os quais, através do processo participam da elaboração do provimento final, atingidor de suas esferas jurídicas. Os litigantes e acusados são sujeitos processuais e não meros objetos ou espectadores, receptores passivos da decisão pronta, sem chance de participar. ${ }^{17}$

É lídimo, pois, afirmar que a distinção que separa o ato administrativo praticado ao fim de um procedimento e o que se pratica ao fim de um processo é essencialmente de regime jurídico, pois, não se concebe processo sem contraditório. ${ }^{18}$

Complementando a idéia, cabe perquirir quando é que exige nossa Constituição o processo, ou seja, quando é que se exige o atendimento do contraditório e da ampla defesa para que se exerça a função administrativa.

Elucidativa a prescrição constitucional que enuncia: "ninguém será privado da liberdade ou de seus bens sem o devido processo legal" (CF/88, art. 5, inc. LIV).

Com efeito, o processo é imprescindível para que se manifeste qualquer ato estatal concreto ${ }^{19}$ tendente a interferir tanto no patrimônio jurídico dos cidadãos (liberdade e propriedade). ${ }^{20} \mathrm{Na}$ diç̧ão elegante e sintética de Marçal Justen Filho: ${ }^{21}$

A invocação constitucional do art. $5^{\circ}$, inc. LV, impôs a observância de um devido processo na via administrativa. Assegurou-se aos particulares o direito à ampla defesa, coma garantia inafastável do contraditório. Tornou-se fora de dúvida que a decisão administrativa, sempre que for apta a produzir o sacrifício de interesses ou direitos privados, deverá ser o resultado de um procedimento administrativo, respeitado o princípio do contraditório.

\footnotetext{
${ }_{17}$ Op. cit., p. 67

${ }^{18}$ No mesmo sentido dos autores ora mencionados, em relação à dicotomia processo/procedimento, levando a análise às minúcias do direito tributário, em obra sem par no nosso direito pátrio, consulte-se: MARINS, James. Direito Processual Tributário Brasileiro (administrativo e judicial). 3. ed. São Paulo: Dialética, 2003.

${ }^{19}$ Diz-se ato concreto, para afastar a idéia de lei (em sentido amplo) que é ato estatal abstrato e genérico que não interfere na esfera jurídica dos cidadãos e sim, verdadeiramente, a define.

${ }^{20}$ Acerca da extensão a ser dada aos vocábulos liberdade e propriedade, como motores do devido processo legal, é de se ver que esses termos não comportam leitura estrita e sim visam à definição da esfera jurídica legitimamente protegida dos cidadãos. Elucidativa neste particular a tradição americana do "due process of law", que mesmo o identificado textualmente, conforme a $5^{\mathrm{a}}$ e a $14^{\mathrm{a}}$ Emendas, com a proteção da vida, da liberdade e do patrimônio reconhece a necessidade da observância do devido processo legal quando houver exercício da atividade do poder público sujeitando a esfera jurídica (individual) dos cidadãos. São tais procedimentos chamados de "administrative adjudication" e o seu sentido não se esgota na proteção da vida, da liberdade e do patrimônio. Para uma análise detida do exposto acerca do direito norte-americano, da onde retiraram-se estas idéias, consulte-se: SCARPINELLA BUENO, Vera. Devido Processo Legal e a Administração Pública no Direito Administrativo Norte-Americano - Uma breve comparação com o caso brasileiro. In: FIGUEIREDO, Lúcia Valle (Coord.). Devido Processo Legal na Administração Pública. São Paulo: Max Limonad, 2001, p. 13-79.

21 "Considerações sobre o Processo Administrativo Fiscal". Revista Dialética de Direito Tributário, n. 33, p. 108. Ressalvamos, contudo, com o máximo acatamento, nos termos já expostos, discordância acerca da conside ração do autor de não haver um processo administrativo propriamente dito, sob o fundamento de que o fenômeno processo cinge-se à jurisdição, necessariamente, haja vista ser seu elemento ôntico, a relação triangular(autor, juiz e réu), que faleceria nas lides administrativas
} 
Neste passo, e indo além no conceito, pode-se dizer que o fenômeno processo administrativo conecta-se com a própria correição do desempenho da função administrativa que deve guardar conformidade com o patrimônio jurídico dos cidadãos, não se tolerando qualquer intervenção que seja desproporcional. Na lição de Vera Scarpinella Bueno: ${ }^{22}$ "O relevante, hoje, é focar o devido processo na ação governamental e na sua necessária razoabilidade, independentemente da qualificação jurídica do direito violado."

Se obviamente o particular não pode pretender interferir no patrimônio de outro sem atentar às garantias do devido processo legal (garantida pela chancela indefectível do Judiciário), também não pode pretender a Administração Pública interferir na esfera jurídica dos cidadãos sem que lhes garanta o devido processo legal. A posição da Administração Pública e suas prerrogativas (donde destacamos a auto-executoriedade) não rendem ensejo para que se rompa com o devido processo legal, caso se verifique a litigiosidade.

Não há posição de supremacia (em nome de interesses públicos) que possa fazer a Administração se arvorar da faculdade de não ofertar o devido processo administrativo. Sem medo de repetição, não está o comando constitucional sujeitos a temperamentos de qualquer ordem, mesmo os advindos de invocações da supremacia do interesse público sobre o privado.

O Texto Magno exige que quando, exercite a Administração determinada competência e tal manifestação implique em ingerência no patrimônio e na liberdade dos cidadãos (i.e. patrimônio jurídico), o ato produzido não se dê por simples procedimento, mas por processo se assim o reclamar o administrado. No momento em que houver a contraposição de interesses entre Administração e cidadãos deverá surgir o processo com todas as suas garantias.

A distinção demonstra sua pertinência pois no primeiro caso não é necessário (conquanto seja facultado) conferir ao cidadão a ampla defesa e o contraditório e no segundo sim. Com efeito, quando o ato a ser produzido implicar em disposição por parte da Administração do patrimônio e da liberdade dos cidadãos, é de manifestar esta competência sob a pauta do processo.

O procedimento indica a maneira como irá se operar a manifestação do exercício do poder público, colocando-o dentro de uma pauta racional e, pois, controlável. A procedimentalidade é ínsita ao agir do Estado. Não

\footnotetext{
22 Op. cit., p. 19.
}

$\overline{\text { A \& C R. de Dir. Administrativo e Constitucional, Belo Horizonte, ano 4, n. 16, p. 193-218, abr./jun. } 2004}$ 
há de se conceber que possa vir a agir o Estado em desconformidade com o procedimento que lhe é imposto pela Lei. Isto por elementar contingência da própria noção de agir estatal, que pressupõe o atendimento de finalidades necessariamente públicas e necessariamente sindicáveis. O procedimento inimigo do arbítrio - é a garantia máxima do controle da Administração.

O processo, para além de indicar como se manifestará o Poder Público, cumpre a função de fazer garantir que o cidadão fará constar suas razões na manifestação do Poder Público que lhe toque a esfera jurídica mais íntima. $\mathrm{O}$ ato que traduz o exercício do poder público no que tange à liberdade e ao patrimônio não pode prescindir de garantir a possibilidade de manifestação do cidadão, e sua juridicidade está condicionada a que se franqueie ao administrado a oportunidade de tomar parte da feitura do ato final.

Enunciando com simplicidade, o comando constitucional impõe que se ouça (ou se dê possibilidade de fazê-lo) o cidadão e se avaliem suas alegações sempre que o Estado pretenda adentrar sua esfera jurídica no que toca à liberdade e ao patrimônio.

Voltando à pesquisa do âmbito de aplicação Lei $n^{\circ}$ 9.784/99, cabe consignar a utilidade da distinção. Antes, ainda, faz-se necessário meditar sobre mais uma disposição constitucional. Cabe, pois, lançar olhos sobre a competência legislativa em matéria processual e procedimental:

Art. 22 - Compete privativamente à União legislar sobre:

I - direito civil, comercial, penal, processual, eleitoral, agrário, marítimo, aeronáutico, espacial e do trabalho; (destacou-se em itálico).

Art. 24 - Compete à União, aos Estados e ao Distrito Federal legislar concorrentemente sobre: (...)

XI - procedimentos em matéria processual; (destacou-se em itálico).

Da análise dos dispositivos que traçam a competência em matéria de processo e em matéria de procedimentos, nota-se que para a Constituição processo e procedimento são realidades inconfundíveis. Pensar de maneira diversa, tomando os vocábulos como sinônimos no plano administrativo, seria anular a inteligência da norma que atribui privativamente, legislar sobre processo, à União.

Se há na Constituição menção tão expressa afirmando que processo e procedimento são realidades distintas (separada pela divisão de competências legislativas), é preciso perquirir qual o sentido que a própria Constituição atribui a tal diferença. Não comporta dúvida que a Constituição concebe conceitos distintos de processo e procedimento, senão não

A \& C R. de Dir. Administrativo e Constitucional, Belo Horizonte, ano 4, n. 16, p. 193-218, abr.jun. 2004 
haveria sentido na atribuição de competências a pessoas políticas distintas.

Volvendo ao que se disse, é preciso encarar o processo como instituto vinculado a situações de conflituosidade, enquanto o procedimento vincula-se ao exercício da função pública (dinamização de competência previamente atribuída).

Ferindo a questão por outra banda, é de se pôr em mira o porquê de a Constituição atribuir à União competência privativa para legislar sobre processo e não sobre procedimento. Novamente, é a posição do devido processo legal enquanto garantia inalienável do cidadão (art. $5^{\circ}$, LV da CF), que tem o condão de aclarar o tema.

Isto pois, afigura-se inconcebível em nosso esquema federativo que questão deste jaez pudesse receber tratamento diverso em diferentes entes federativos.

Referindo a questão sob o prisma do processo administrativo, objeto imediato deste estudo, pensar que em diferentes quadrantes da Administração pudessem ser concebidos diferentes processos administrativos (na acepção em que a Constituição emprega o termo) seria negar a unidade constitucional do processo.

No que toca a assegurar-se o contraditório, a ampla defesa com os meios e recursos a ela inerentes, há de se respeitar a unidade constitucional. Isso não significa negar em absoluto a competência de outros entes federativos para legislar sobre o tema, conquanto tratem de procedimento, ou impingir a pecha de nulidade a procedimentos específicos regulados por leis próprias que visam a resguardar especificidades de setores onde haja particularidades.

A distinção entre processo e procedimento é pressuposto para que se fixe o âmbito de alcance da lei, não só por ser inconcebível pretender que se dê trato distinto ao devido processo legal em diferentes entes federativos, mas também por ser explícita a atribuição privativa da União para legislar sobre processo, conceito que se reveste de conteúdo próprio na Constituição.

Como visto, processo - para a Constituição Federal — assume significação diametralmente oposta de procedimento, submetendo a Administração, quando no exercício das competências que lhe são atribuídas, a um regime jurídico diverso. Regime que se qualifica pela necessária participação do cidadão (ampla defesa e contraditório) para produção do ato final (terminativo da conflituosidade).

A \& C R. de Dir. Administrativo e Constitucional, Belo Horizonte, ano 4, n. 16, p. 193-218, abr./jun. 2004 
Ao atribuir competência à União para legislar sobre processo, e ao ter fixado o conceito ao atendimento efetivo da ampla defesa e do contraditório, infere-se que a descrição legislativa que venha a concretizar o devido processo legal valha para toda a Federação.

Isto, por conta de duas conclusões inesquiváveis que se haurem da Constituição: (i) dignidade constitucional do processo administrativo e (ii) reconhecimento da distinção entre processo e procedimento, inclusive quanto ao exercício da competência legislativa. Postos estes aclaramentos, cabe fazer breve síntese das idéias expostas explicitando o âmbito de aplicação da Lei $\mathrm{n}^{\circ}$ 9.784/99, consoante as premissas que se traçaram.

\subsection{Fixação do alcance da Lei e interpretação possível da reserva federativa do seu art. $1^{\circ}$, caput}

Finalmente, cabe pôr em elenco mais sistemático as considerações acima expendidas para que se fixe o âmbito de incidência da Lei $\mathrm{n}^{\mathrm{o}}$ 9.784/99, que, como visto, vai mais além do que o âmbito da Administração Federal.

Como visto, o primeiro predicado metodológico a ser reclamado do intérprete quando do trato com o diploma legal é que seja feita a distinção entre processo e procedimento. Em verdade, nem todas as regras (produtos da interpretação) contidas na Lei vão se orientar à prática de atos terminativos de conflitos e, pois, nem todas as prescrições representam regras de processo administrativo, consoante aqui definido. ${ }^{23}$

Isto é, na Lei $n^{\circ}$ 9.784/99 estão contidas regras de processo e procedimento e sua identificação é que comanda a sua aplicação escorreita.

Primeiramente, cumpre consignar, até pelo tudo o que se expôs, que as regras da Lei ${ }^{\circ}$ 9.784/99 que tocam ao instituto "processo" devem ser aplicadas em todos os quadrantes da Administração.

Onde se identificarem as regras da LPAF com o atendimento do contraditório, da ampla defesa e as garantias a ela inerentes, há de se aplicá-las, sem qualquer sorte de reserva em função de não se poder negar ao cidadão as garantias do devido processo legal. ${ }^{24}$

Não se trata neste caso de extensão analógica, principiológica, âplicação subsidiária, supletiva ou cojisa que o valha; as regras da Lei de no direito administrativo. É o que se passa, por exemplo, com a identificação das regras da Lei Geral de Licitações que assumem o caráter de "normas gerais", que condicionam à sua observância todos os entes federativos e as normas que não se revestem desta natureza que podem ser alteradas pelos Estados, Municípios e Distrito Federal. É o que Marçal JUSTEN FILHO chama de "questão topológica" (Comentários à Lei de Licitação e Contratos Administrativos. 8. ed. São Paulo: Dialética, 2002, p. 15). 
Processo Administrativo aplicam-se diretamente ao âmbito Distrital, Estadual ou Municipal quando se tratarem de regras de processo.

Na doutrina, sustentam Nelson Nery Júnior e Rosa Maria de Andrade Nery que a aplicação das normas principiológicas da LPAF teriam aplicação imediata para além da esfera Federal e que as normas gerais aplicar-se-iam em caso de lacuna nas leis que disciplinam processos específicos. ${ }^{25}$ Sem embargo deste ponto de vista, crê-se que o fenômeno é diverso.

Não é pelo fato de as normas serem principiológicas ou pelo fato de serem gerais que se aplicará a Lei n ${ }^{\circ}$ 9.784/99 a hipóteses que vão além do âmbito Federal. Esta aplicação é regida pelo critério constitucional. Não é qualquer juízo em relação à estrutura da norma que rege a aplicação da Lei $\mathrm{n}^{\circ}$ 9.784/99 além do âmbito Federal. É, sim, o simples fato de se identificar uma regra como garantidora do devido processo administrativo.

Ou seja, quando as regras da LPAF forem normas processuais (garantam o devido processo administrativo) elas devem ser aplicadas, não por serem gerais ou principiológicas, mas por serem elas que garantem a efetivação dos comandos indefectíveis da Constituição atendendo à competência legislativa para tanto.

O exercício por parte da União da sua competência privativa para legislar sobre processo, vincula a aplicação direta da Lei $n^{0} 9.784 / 99$ em todos os níveis da Administração Pública, quando se identificarem suas prescrições como sendo relativas a processo, ou seja, quando estas regras cuidarem de garantir ao cidadão contraditório e ampla defesa.

Porém, para que não quede vazia de sentido a restrição enunciada no art. $1^{\circ}$, que limita a aplicação da Lei ao âmbito da Administração Federal, é necessário buscar o sentido possível que ela pode assumir. Neste passo, impende dizer que as regras que tratarem de procedimento (enquanto exercício de competência sem necessário atendimento da participação do cidadão) devem vincular apenas a Administração Federal.

Apenas neste caso (regra de procedimento) faz sentido a enun-

\footnotetext{
${ }^{24}$ Cumpre fazer ressalva em face de normas específicas que neste caso terão precedência nos termos da LPAF, art. 69. Contudo, é de se dizer que não é a mera existência de lei específica em relação a um tema, que fixe normas acerca de um determinado processo, que governa a dispensa da aplicação das normas previstas na lei geral, há de ser levado a efeito minudente juízo de compatibilidade e aplicar-se-á a LPAF em tudo aquilo que não houver norma específica em sentido diverso. É a opinião de SUNDFELD, Carlos Ari. Processo e Procedimento Administrativo no Brasil. In: As Leis do Processo Administrativo - Lei Federal 9.784/99 e Lei Paulista 10.177/98. São Paulo: Malheiros, 2000, p. 27

25 NERY JR., Nelson; NERY, Rosa Maria de Andrade. Código de Processo Civil Comentado e Legislação Processual Civil Extravagante em Vigor. 6. ed. São Paulo: Revista dos Tribunais, p. 1.437 (comentários ao art. $1^{\circ}$ da Lei 9.784)
}

A \& C R. de Dir. Administrativo e Constitucional, Belo Horizonte, ano 4, n. 16, p. 193-218, abr.jun. 2004 
ciação do princípio federativo para legitimar a aplicação restrita da Lei de Processo à Administração Federal. Neste caso, cumpre dizer que não poderia de maneira alguma a lei editada pela União dizer como se procederá ao exercício da função administrativa nos outros escaninhos da Administração. A autonomia dos entes da Federação não admite esta sorte de ingerência, sendo que a elas incumbe tratar de como exercerão sua função administrativa.

Enfim, em rasa síntese, no que tange às regras de processo, a Lei $n^{o}$ 9.784/99 deve ser aplicada a todos os quadrantes da Administração Pública e, no que toca ao procedimento, restrita está sua aplicação ao âmbito Federal.

\section{Comentários ao $\S 1^{\circ}$ : Do exercício da função administrativa como critério de fixação da incidência da Lei n 9.784/99}

O parágrafo primeiro da LPAF trata de dizer que mesmo para além da Administração Pública aplicam-se suas previsões quando haja o exercício da função administrativa no seio dos Poderes Judiciário e Legislativo.

Além do didatismo da proposição, encerra-se em seu bojo conceito dos mais importantes. Note-se, que a incidência da Lei está jungida ao exercício da função administrativa, conceito este, hoje, por estrutural, imprescindível para compreensão do próprio direito administrativo.

Pode-se definir por função, em direito, a necessária relação ao atendimento de interesses alheios quando no exercício de uma prerrogativa. $\mathrm{O}$ fato de haver prerrogativas em si não diz nada; o que se põe em mira é que elas estejam a atender um fim que é alheio ao seu titular. É o legítimo atendimento de finalidades alheias ao detentor da prerrogativa a nota essencial da função. É o próprio dever de dar guarida ao interesse de outrem que legitima haver prerrogativas.

Outro não é o fenômeno que caracteriza o direito administrativo, ${ }^{26}$ onde todas as prerrogativas que se concedem à Administração visam a atender finalidades públicas. Ou seja, as prerrogativas da Administração hão de ser manejadas sempre colimando o atendimento de finalidades públicas, que por vezes não se confundem com os seus próprios interesses. Ousa-se dizer que justamente a fixação da incidência do regime jurídico administrativo é a chave de abóboda para compreender a função administrativa, compreendendo dialeticamente o regime de prerrogativa e sujeições, enfim, compreender o próprio direito administrativo. ${ }^{27}$

Trazem-se estes conceitos haja vista seu manifesto valor meto

\footnotetext{
${ }^{26}$ Sobre o tema, por inexcedível, consulte-se: MELLO, Celso Antônio Bandeira de. Discricionariedade e Controle Jurisdicional. 2. ed. São Paulo: Malheiros, 1993, em especial o cap. II.
}

A \& C R. de Dir. Administrativo e Constitucional, Belo Horizonte, ano 4, n. 16, p. 193-218, abr.jun. 2004 
dológico quando do trato com a LPAF, justamente auxiliando a determinar seu âmbito de incidência. Para mais que buscar fixar se determinada atividade está contida ou não neste art. $1^{\circ}$ em função do sujeito que pratica o ato e está a exercer competência, deve se perguntar se há o exercício de função no caso em análise; se a resposta for positiva, necessariamente — lembrados os temperamentos feitos acima — aplicam-se as disposições contidas na Lei.

Em síntese, onde manifestar-se função administrativa aplicar-se-ão os preceitos da Lei $n^{\circ}$ 9.784/99, com as ressalvas feitas ao se comentar o caput do presente artigo.

\section{Comentários ao §2॰: Impossibilidade de se determinar a incidência da LPAF exclusivamente pelo critério orgânico ou subjetivo}

Por fim, seguindo em seu didatismo, classifica a Lei o que se entenderá por órgão, entidade e autoridade. Cumpre, antes de analisar estas categorias, fazer advertência vestibular. Note-se, inicialmente, que para os fins da Lei não se adota classificação em tela como sendo absolutamente rígida podendo levar o interprete à tentação de restringir a aplicação da Lei no 9.784/99 em função dos critérios subjetivos lá definidos, tomando-a por exaustiva.

Define o Decreto-Lei n ${ }^{\circ} 200$, de 25.06.1967, em seu art. $4^{\circ}$, os entes que compõem a Administração Pública, subjetivamente considerada. ${ }^{28}$ Trata este diploma da Administração direta (serviços integrados na estrutura administrativa) e da indireta (entidades personalizadas) composta por: a) Autarquias; b) Empresas Públicas; c) Sociedades de Economia Mista e c) Fundações Públicas. ${ }^{29}{ }^{30} \mathrm{~A}$ alusão à Administração direta e indireta consta também do caput do art. $1^{\circ}$ da Lei 9.784/99.

Por seu turno, a previsão do $\S 2^{\circ}$ trata de mencionar nos incs. I e II

${ }^{27}$ Novamente torna-se imperioso citar: MELLO, Celso Antônio Bandeira de. Curso de Direito Administrativo. 14. ed. São Paulo: Malheiros, 2002, fundamentalmente o Cap. I, donde se extrai a elucidativa passagem que demonstra a utilidade de adotar estes primados como método de trabalho, em função de seu elevado valor metodológico: "O sistema de uma disciplina jurídica, seu regime, portanto, constitui-se do conjunto de princípios que Ihe dão especificidade em relação ao regime de outras disciplinas. Por conseguinte, todos os institutos que abarca - à moda do sistema solar dentro do planetário - articulam-se, gravitam, equilibramse, em função da racionalidade própria deste sistema específico, segundo as peculiaridades que delineiam o regime (no caso, o administrativo) dando-Ihe tipicidade em relação aos outros. (...) De todo exposto se verifica a grande importância da noção de regime administrativo, cujo desenvolvimento pormenorizado é o objeto deste próprio ramo do direito" (in p. 63 e 64).

${ }^{28}$ Art. $4^{\circ}$ A Administração Federal compreende: I - A Administração Direta, que se constitui dos serviços integrados na estrutura administrativa da Presidência da República e dos Ministérios. II - A Administração Indireta, que compreende as seguintes categorias de entidades, dotadas de personalidade jurídica própria: a) Autarquias; b) Empresas Públicas; c) Sociedades de Economia Mista.(...) (Preservou-se a redação original). 
o que se compreende por órgão e por entidade, distingüindo-os em função da sua personalização ou não.

Nota-se, destarte, que a classificação subjetiva referente à atividade administrativa não é estranha à Lei de Processo Administrativo, haja vista em seu art. $1^{\circ}$ constar referência à Administração direta e indireta (caput) e aos fenômenos da desconcentração ( $2^{\circ}$, I - órgão) e da descentralização ( $\$ 2^{\circ}, I$ - entidade). Contudo, esta classificação não esgota o fenômeno da incidência da Lei $\mathrm{n}^{\circ}$ 9.784/99, aplicando-se a Lei exclusivamente em função dos sujeitos integrantes da Administração direta e indireta (cf. Decreto-Lei no 200 de 1967).

O critério de incidência da Lei $n^{0} 9.784 / 99$ é material e exsurge em função do exercício de função administrativa, mesmo que para além das previsões expressas deste $\$ 2^{\circ}$.

Ao fixar o que se compreende por órgão, entidade e autoridade e as categorias integrantes da Administração direta e indireta, não se está a restringir a aplicação apenas ao que possa imediatamente ser identificado com estas figuras. Isto porque a incidência da Lei $9.784 / 99$ rege-se pelo exercício da função administrativa. É este o único método de trabalho idôneo a explicitar com precisão a incidência da Lei.

Assume relevo tal advertência pois as prescrições contidas no $2^{\circ}$ só podem ser compreendidas sob este enfoque, não cabendo qualquer reducionismo em função exclusivamente do critério subjetivo que é meramente auxiliar.

Pensar de modo diverso seria o angustiamento da dignidade constitucional do processo administrativo que se faz imperativo quando da prática de atos que possam importar em interferência do patrimônio jurídico dos cidadãos. À completude da garantia constitucional, não pode ser oposto o critério subjetivo definido em lei.

Para fins da aplicação escorreita da LPAF, mais do que a classificação das diferentes instâncias da Administração Pública em função dos sujeitos que a integram (levando em conta os fenômenos da concentração e desconcentração), é de se ter em mira que suas prescrições aplicam-se tanto caso não haja personalidade jurídica própria (no caso dos órgãos), quanto caso haja personalidade própria (no caso das entidades), bem como, nos

\footnotetext{
${ }^{29}$ Redação dada pelo art. 10, I da Lei n $7.596 / 87$.

${ }^{30}$ No que tange à classificação proposta pelo Decreto-Lei 200 de 1967, é de se ver que ela não é exclusiva do âmbito Federal, as categorias mencionadas aplicam-se ao âmbito, Estadual, Municipal e Distrital (cf. DI PIETRO; Maria Sylvia Zanella. Direito Administrativo. 10. ed. São Paulo: Atlas, 1999, p. 56).
} 
casos de haver poder de decisão (exercido por autoridade), ou quaisquer outros casos. Basta que se verifique exercício de função administrativa.

Não se pode pretender que a incidência da Lei de Processo esteja sujeita a considerações bizantinas a respeito de elementos de classificação da atividade administrativa em função de critérios meramente subjetivos. As classificações, conforme lição já célebre, são sindicadas pelo critério de sua utilidade, não sendo idôneo pôr em xeque a essência do que se pretende ordenar em função do critério de ordenação eleito. Ou seja, não é lícito com base na classificação buscar explicar o fenômeno classificado, por evidente tautologia do raciocínio.

Adverte Celso Antônio Bandeira de Mello que não se reduz o fenômeno do exercício da função administrativa à enunciação legal dos sujeitos que integram a Administração (como poderia se supor de uma leitura precipitada do art. $1^{\circ}$ da Lei $n^{\circ} 9.784 / 99$, ou do Decreto-Lei $n^{\circ} 200$ de 1967): ${ }^{31}$

Percebe-se que o critério retor da classificação foi o orgânico, também chamado subjetivo. (...) O modelo destarte concebido, é bem de ver, revela-se inapto para descortinar todas as modalidades pelas quais se desempenham atividades administrativas públicas. Com efeito, a expressão "Administração indireta", que doutrinariamente deveria coincidir com "Administração descentralizada", dela se afasta parcialmente. Por isto ficaram de fora da categorização como Administração indireta os casos em que a atividade administrativa é prestada por particulares, "concessionários de serviços públicos", ou por delegados de função ou ofício público.

Logo, ao se interpretar o $\$ 2^{\circ}$ é de se ter em mira que é perfeitamente possível que se aplique à Lei para além do que se define (em especial, levando em conta o disposto no Decreto-Lei $\mathrm{n}^{\mathrm{O}} 200$ ) por órgão, entidade $\mathrm{e}$ autoridade, basta que haja exercício de função administrativa.

Apenas o exercício da função administrativa está apto a determinar a incidência da LPAF, juizo que não pode ser suplantado por nenhuma consideração de ordem subjetiva.

Tanto é assim que, mesmo além do aparato da Administração, quer direta, quer indireta, aplicam-se as disposições da Lei, como bem se lê no $\S 1^{\circ}$ que fixa a incidência dos seus dispositivos no âmbito do Legislativo e Judiciário quando a função que se está a desenvolver é administrativa. A prescrição do parágrafo anterior é clara ao sufragar as alegações vestibulares.

${ }^{31}$ MELLO, Celso Antônio Bandeira de. Curso de Direito Administrativo. 14. ed. São Paulo: Malheiros, 2002,p.137.

A \& C R. de Dir. Administrativo e Constitucional, Belo Horizonte, ano 4, n. 16, p. 193-218, abr.jun. 2004 
Cabe, enfim, analisar brevemente os conceitos dos incisos do $§ 2^{\circ} \mathrm{e}$ o seu sentido em relação ao processo administrativo como entidade autônoma, atentos à advertência feita ao longo deste tópico de que estes critérios são auxiliares, contudo não têm aptidão de definir por si, quando a relação deve se dar sob o influxo do processo e das regras a ele inerentes.

Órgãos (inciso I), como assinala a unanimidade da doutrina, são apêndices de pessoas jurídicas que integram a Administração Pública ${ }^{32}$ que não possuem personalidade jurídica própria. Assim, é característica essencial do órgão, não possuir personalidade jurídica própria. O que identifica o órgão é o singelo exercício de competências que lhe são outorgadas pela pessoa jurídica a qual ele está jungido, desde, claro, que esta outorga afigure-se legítima. Sobre o tema, assinala Celso Antônio Bandeira de Mello:

Os órgãos não passam de simples partições internas da pessoa cuja intimidade integram, isto é, não tem a personalidade jurídica (...) Em síntese, juridicamente falando, não há, em sentido próprio, relação entre órgãos, e muito menos entre eles e outras pessoas, visto que, não tendo personalidade, os órgãos não podem ser sujeitos de direitos e obrigações. ${ }^{33}$

Identifica-se órgão em função do exercício de competência (mesmo que seja de julgamento), sem que no entanto este exercício possa vir a instaurar uma relação autônoma entre o órgão e quem quer que seja. Tal advertência assume extremo relevo no que toca ao estudo do âmbito do processo administrativo, para que não se incida no vício de se supor que a relação processual vincula o órgão propriamente dito. Mesmo que o órgão exerça uma competência decisória, por exemplo nos termos do art. 11 da $\mathrm{LPAF}^{34}{ }^{34}$ é de se ver que tal fenômeno decorre de uma partição interna de competências e não autoriza a suposição de haver relação entre o órgão e quem quer que seja. Neste caso, o órgão será incumbido da tramitação do processo, contudo o provimento final a ser exarado não sujeita o órgão a

\footnotetext{
32 Por vezes, identificam-se os órgãos exclusivamente como produto da desconcentração efetuada dentro do seio da Administração Pública direta, sendo este fenômeno estranho à Administração indireta. É, neste sentido, o magistério abalizado de Maria Sylvia ZANELLA DI PIETRO: "compõem a Administração Pública em sentido subjetivo, todos os órgãos integrantes das pessoas jurídicas políticas (União, Estados, Municípios e Distrito Federal) aos quais a lei confere o exercício de funções administrativas. São os órgãos da Administra ção Direta do Estado" (Direito Administrativo. 10. ed. São Paulo: Atlas, 1999, p. 56). Com a escusa do entendimento transcrito, crê-se nada obstar que o fenômeno se dê no bojo da Administração indireta, nada vedando que seus integrantes deleguem funções dentro da estrutura com vistas a melhor atender as suas finalidades. Neste sentido pertine a alusão de órgãos integrantes da Administração indireta. Parece ser inclusive este o espírito da Lei 9.784/99 que identifica órgãos tanto no bojo da Administração direta, quanto

33 Op. cit., p. 122-123. indireta.
}

A \& C R. de Dir. Administrativo e Constitucional, Belo Horizonte, ano 4, n. 16, p. 193-218, abr.jun. 2004 
nada e sim vincula a entidade efetivamente dotada de personalidade.

A relação vincula o ente efetivamente dotado de personalidade ao qual o órgão está sujeito. Os órgãos têm relevo para a lei na medida em que, nada obstante não seja parte da relação processual, eles são focos de competência. Além da possibilidade de haver órgãos com competências decisórias eles podem ser chamados a participar da prática de certos atos processuais, sem contudo assumir a condição de parte (pois não estão vinculados ao provimento final). Neste sentido, temos o exemplo, v.g., de pareceres que devem ser exarados para a instrução do processo, dentre outros exemplos que podem ser colhidos da LPAF. ${ }^{35}$

Entidades (inciso II), para fins da LPAF, são todos os entes que exercem função administrativa - "unidade de atuação" (em regime de prerrogativas e sujeições), dotados de personalidade jurídica própria. Como avulta com clareza da análise dos dispositivos em análise, distinguem-se os órgãos das entidades em face da presença ou não de personalidade jurídica. Acresça-se a isto, que é irrelevante para fins de determinar a incidência ou não de regras de processo administrativo que a personalidade seja de direito público, pois, nos casos em que se estiver diante de pessoa de direito privado que esteja fazendo as vezes do Estado devem incidir tais normas no que houver exercício de função administrativa. Veja-se com isto, que estão a ser rompidos os cânones do DL n ${ }^{0}$ 200/67 por não se adotar o critério de administração direta ou indireta (como se faz tradicionalmente) e sim vincular, à relação processual, as entidades dotadas de personalidade própria.

Nos casos onde haja personalidade jurídica própria a relação processual se estabelece diretamente com a entidade, que age em nome próprio e responde, portanto, seus atos.

Por fim, autoridade (inciso III) é conceito que vem vincular os agentes que desempenham em concreto a função pública, haja vista as pessoas morais não agirem concretamente, senão por meio de pessoas naturais que dão animo às previsões abstratas que estruturam as personalidades advindas da razão legal. ${ }^{36}$ Novamente, o critério é de auxílio na medida em que mesmo sem as autoridades integrarem diretamente o processo administrativo

\footnotetext{
34 "Art. 11. A competência é irrenunciável e se exerce pelos órgãos administrativos a que foi atribuída como própria, salvo os casos de delegação e avocação legalmente admitidos."

35 A título meramente exemplificativo é possível consultar os seguintes artigos: "Art. 35. Quando necessária à instrução do processo, a audiência de outros órgãos ou entidades administrativas poderá ser realizada em reunião conjunta, com a participação de titulares ou representantes dos órgãos competentes, lavrando-se a respectiva ata, a ser juntada aos autos": "Art. 42. Quando deva ser obrigatoriamente ouvido um órgão consultivo, o parecer deverá ser emitido no prazo máximo de quinze dias, salvo norma especial ou compro vada necessidade de maior prazo", dentre outros que fixam a participação de órgãos no correr do processo.
} 
devem dele participar, por vezes. Assim não estão indenes da aplicação da Lei, naquilo que lhes for pertinente, as autoridades, quando chamadas a participar da relação processual administrativa.

O que importa concluir da análise da classificação imposta pela LPAF, é que mais importante do que tentar determinar o seu âmbito de incidência com fulcro na classificação proposta, é notar que o critério que governa sua aplicação (em especial, no que toca a processo propriamente dito) é o desempenho de função público sob o influxo do regime jurídico administrativo (prerrogativas e sugestões). Os conceitos postos em elenco são instrumentais e não bastam por si sós para definir a incidência ou não das normas de processo contidas na Lei; é a dignidade constitucional do instituto que não permite o reducionismo de se tomar a classificação como essência.

\section{Conclusões pontuais}

A análise do art. $1^{\circ}$ da LPAF, como tentou demonstrar-se, rende ensejo a vastas considerações acerca do tema processo administrativo. Algumas delas buscou-se tratar com minudência, outras apenas ficaram indicadas ou sugeridas em nome da delimitação proposta. O que é de se ter por definitivo é que nada do conteúdo apresentado está indene de crítica, o objetivo único era lançar algumas inflexões críticas acerca do tema processo administrativo que está a merecer maiores atenções.

Contudo, a bem da operacionalidade e da ampla possibilidade de sindicância, faz-se necessário apresentar um arremate para a discussão proposta. Seguindo a linha metodológica adotada, que reclama análise crítica das propostas apresentadas, melhor será fazer uma recolha dos pontos defendidos do que arvorar-se de proposições que incidam no vezo de pretender a perenidade.

Em rasa síntese, reduz-se o texto aos seguintes pontos de discussão: 1. contraditório e ampla defesa são garantias fundamentais que sujeitam todo o exercício do poder estatal (funções executiva, legislativa e judiciária) à sua irrestrita observância;

\footnotetext{
${ }^{36}$ Neste ponto é de se destacar a crítica de CARVALHO FILHO, José dos Santos (In: Processo Administrativo Federal - comentários à Lei 9.784 de 29.01.1999. Rio de Janeiro: Lumen Juris, 2001, p. 47-48 et seq.) que prefere a dicção "agentes públicos" que seria gênero. Parece-nos, contudo, que a dicção "autoridade", por ter assento constitucional, (art. 5, ${ }^{\circ}$ LXIX) não padece de nenhuma imprecisão digna de crítica.
} 
2. tal garantia é una em todos os quadrantes da Federação, devendo ser ofertado integralmente o devido processo legal toda vez que a Constituição o impuser como necessário à prática de atos estatais;

3. processo e procedimento no que toca ao exercício de função administrativa são conceitos distintos face à Constituição sendo modos absolutamente diferentes de desempenhar/concretizar as competências conferidas à Administração;

4. processo, por injunção constitucional, vincula-se à noção de conflituosidade que se, e quando, verificada predica o contraditório e a ampla defesa, agregando necessariamente a participação do interessado para a prática do ato que institucionalmente compõe o conflito;

5. procedimento, ao seu turno, indica a maneira como irá se concretizar a possibilidade de agir outorgada abstratamente por uma competência previamente delimitada, circunscrevendo o agir da Administração dentro de uma pauta racional e, pois, controlável;

6. nos termos da Constituição Federal, "processo" e "procedimento" são realidades inconfundíveis, pensar de modo diverso seria anular a inteligências da norma que atribui exclusivamente à União legislar sobre processo.

7. as normas de processo vertidas na LPAF (enquanto normas que se vinculam a compor conflitos tratado de contraditório e ampla defesa) devem ser aplicadas para além da esfera federal, valendo para o Distrito Federal, Estados e Municípios também;

8. já as normas que se referem a procedimento, que não cuidem do devido processo legal, têm sua aplicabilidade restrita ao âmbito federal apenas;

9. é o exercício por parte da União da sua competência privativa para legislar sobre processo que vincula a aplicação direta da Lei $\mathrm{n}^{\circ}$ 9.784/99 em todos os níveis da Administração Pública;

A \& C R. de Dir. Administrativo e Constitucional, Belo Horizonte, ano 4, n. 16, p. 193-218, abr.jun. 2004 
10. o critério que governa a aplicação da lei é material e vinculase ao exercício de função administrativa voltada a surtir efeitos no patrimônio jurídico dos cidadãos e independe da adoção de critérios subjetivos ou orgânicos.

A \& C R. de Dir. Administrativo e Constitucional, Belo Horizonte, ano 4, n. 16, p. 193-218, abr.jun. 2004 